\title{
Bioremediation and Detoxification of Trypan Blue by Bacillus sp. Isolated from Textile Effluents
}

\author{
P. Jeevitha, D. Manjula, I. Ramya and J. Hemapriya*
}

Department of Microbiology, DKM College for women, Vellore, India

*Corresponding author

\section{A B S T R A C T}

\section{Keywords}

Azo dyes, Trypan

blue, Bacillus sp.,

Azoreductase,

Lignin Peroxidase

Article Info

Accepted:

25 June 2018

Available Online:

10 July 2018
Azo dyes are commonly used in many commercial industries. 16 bacterial isolates were isolated from textile effluents, of which 4 isolates (HB1, HB2, HB3 and HB4) showed ability to decolorize Trypan blue dye. Based on the standard morphological and biochemical characteristics, HB3 isolate that showed maximum decolorization of Trypan blue was identified as Bacillus sp. HB3 isolate showed $96.6 \%$ decolorization of Trypan blue within $24 \mathrm{~h}$ of incubation. Maximum decolorization of Trypan blue was found to be achieved at $35^{\circ} \mathrm{C}$, neutral $\mathrm{pH}$ in the presence of glucose (Carbon source) and Yeast extract (Nitrogen source). The activity of azo reductase, lignin peroxidase, tyrosinase, manganese Peroxidase was investigated for their role in biodegradation of Trypan blue. Specific activity of the azoreductase enzyme was found to be $0.46 \mathrm{U} \mathrm{mg}^{-1}$ protein. The crude protein extract subjected to SDS-PAGE resulted in the formation of a clear band (original band) against blue back ground which indicated the location of active azoreductase enzyme

\section{Introduction}

Azo dyes are the largest group of synthetic chemicals that are widely employed in the textile, leather, cosmetics, food coloring and paper production industries.

The chemical structure of these compounds features substituted aromatic rings that are joined by one or more azo groups $(-\mathrm{N}=\mathrm{N}-)$. The annual world production of azo dyes is estimated to be around one million tons (Pandey et al., 2007) and more than 2000 structurally different azo dyes are currently in use (Vijaykumar et al., 2007). During the dyeing process, approximately $10-15 \%$ of the used dye is released into wastewater (Asad et al., 2007). Moreover, many azo dyes and their degradation intermediates such aromatic amines are mutagenic and carcinogenic and discharge of them into surface water obstructs light penetration and oxygen transfer into bodies of water, hence affecting aquatic life (Ozturk and Abdullah, 2006).

Most of dyes have a synthetic origin and complex aromatic molecular structure, which make them stable and difficult to biodegrade. Reactive dyes differ from all other dye classes in that they bind to textile fibers, such as cellulose and cotton, through covalent bonds (O’Mahony et al., 2002). Reactive dyes are 
typically azo-based chromophores combined with various types of reactive groups, which show different reactivity. The recalcitrance of azo dyes has been attributed to the presence of sulfonate groups and azo bonds, two features generally considered as xenobiotic (Rieger et al., 2002). Some of the azo dyes are difficult to treat by conventional wastewater treatment methods. Compared with physical and chemical methods, biological techniques are preferable because of economical advantages and eco safety.

Many microbial strains have been isolated to degrade this kind of aromatic compound (Rajaguru et al., 2000; Stolz, 2001). Most of the metabolic studies have been limited to bacterial genera; however, since azo dyes are considerably recalcitrant (Pagga and Brown, 1986). The reduction of azo dyes leads to formation of aromatic amines which are known mutagens and carcinogens.

Further it is difficult to degrade these aromatic amines containing waste water by conventional treatment processes. Hence, economical and eco-friendly approaches are needed to remediate dye-contaminated wastewater from various industries.

Among the various bioremediation technologies, decolorization using microbial cells has been widely used. The anaerobic reduction of azo linkages converts the azo dyes to usually colorless but potentially harmful aromatic amines. The anaerobic reduction of the produced aromatic amines can be converted into non-harmful products by several bacterial strains under aerobic condition by their reductive mechanisms. From this is evident that bacteria are rarely able to decolorize azo compound in the presence of oxygen (Chang et al., 2001). This study was an attempt to isolate the bacterial strains which could decolorize the azo dyes even in aerobic condition.

\section{Materials and Methods}

\section{Sampling sites and Textile dyes used}

The sampling area was the textile industries and dyeing units located in and around Gudiyatham, Vellore District, Tamil Nadu, India. Trypan Blue used in this study was procured commercially. Stock solution was prepared by dissolving $1 \mathrm{~g}$ of the dye in 100 $\mathrm{ml}$ distilled water.

\section{Isolation and Screening of Bacterial Strains Decolorizing Azo dye}

The effluent and sludge samples were serially diluted and spread over minimal agar medium containing $50 \mathrm{ppm}$ of Trypan Blue. $\mathrm{pH}$ was adjusted to 7.0 before autoclaving and incubated at $37^{\circ} \mathrm{C}$ for 5 days. Colonies surrounded by halo (decolorized) zones were picked and streaked on minimal agar medium containing azo dye. The pure cultures were maintained on dye-containing nutrient agar slants at $4^{\circ} \mathrm{C}$.

\section{Decolorization Assay}

Loopful of bacterial culture was inoculated in Erlenmeyer flask containing $100 \mathrm{ml}$ of nutrient broth and incubated at $150 \mathrm{rpm}$ at 37 ${ }^{\circ} \mathrm{C}$ for $24 \mathrm{~h}$.

Then, $1 \mathrm{ml}$ of $24 \mathrm{~h}$ old culture of the bacterial isolates were inoculated in $100 \mathrm{ml}$ of nutrient broth containing $50 \mathrm{ppm}$ of Trypan Blue and re-incubated at $37{ }^{\circ} \mathrm{C}$ till complete decolorization occurs. Suitable control without any inoculum was also run along with experimental flasks. $1 \mathrm{ml}$ of sample was withdrawn every $24 \mathrm{~h}$ and centrifuged at $10,000 \mathrm{rpm}$ for $15 \mathrm{~min}$. Decolorization extent was determined by measuring the absorbance of the culture supernatant at $547 \mathrm{~nm}$ using UV-visible spectrophotometer, according to Hemapriya et al., (2010). 
Dye (i) - Dye (r)
Decolorization efficiency $(\%)=\frac{\text { Dye }(i)}{}$---- 100

Where, Dye (i) refers to the initial dye concentration and Dye (r) refers to the residual dye concentration. Decolorization experiments were performed in triplicates.

\section{Optimization of Culture Conditions for Dye} Decolorization by Bacillus sp. HB3

\section{Effect of Temperature, $\mathrm{pH}$ and Dye Concentration}

The effect of temperature, $\mathrm{pH}$ and dye concentration on dye decolorizing ability of the isolate was studied. This was carried out by incubating the bacterial strains at different temperature $\left(25-45^{\circ} \mathrm{C}\right), \mathrm{pH}(5-9)$ and various dye concentrations (100-500 ppm).

\section{Effect of Carbon and Nitrogen source on Dye Decolorization}

To investigate the effect of various carbon and nitrogen sources, different carbon sources such as, glucose, lactose, and sucrose (1\%) and different nitrogen sources like yeast extract, beef extract, and peptone $(1 \%)$ were added as a supplement individually to Nutrient broth medium for decolorization of Tryphan Blue.

\section{Enzyme Assays}

Assay was carried out in cuvettes with a total volume of $1 \mathrm{ml}$. One unit per enzyme activity was defined as the amount of enzyme that transformed $1 \mu \mathrm{mol}$ of substrate per minute (1 unit = $1 \mathrm{U})$.

\section{Preparation of Cell Free Extract}

The bacterial strain HB3 was inoculated in Nutrient Broth containing Azo dye (Trypan
Blue) and incubated at $37{ }^{\circ} \mathrm{C}$. The cells were harvested by centrifugation at $7000 \mathrm{rpm}$ for 30 min in cooling centrifuge, washed with 50 $\mathrm{mM}$ phosphate buffer ( $\mathrm{pH}$ 7.0) and resuspended in the same buffer.

Then, the cells were disturbed and cell debris was removed by centrifugation at $4{ }^{\circ} \mathrm{C}$. The resultant supernatant was used as the source of crude protein / enzyme.

\section{Laccase Activity Assay}

Laccase activity was determined using 2,2'azino-di-(-3-ethylbenzo-thiazoline-6-sulfonic acid) (ABTS) as the substrate.

$5 \mu \mathrm{l}$ of $50 \mathrm{mM}$ citrate buffer $(\mathrm{pH} 4.0)$ was mixed with $430 \mu 1$ of distilled water and $20 \mu 1$ of laccase.

The reaction was started by addition of $50 \mu 1$ of $6 \mathrm{mM} \mathrm{ABTS}$ and increase in absorbance at $547 \mathrm{~nm}$ was monitored. The enzyme activity was calculated using an extinction coefficient of ABTS of $\varepsilon_{436}=36 \mathrm{~m} \mathrm{~mol}^{-1} \mathrm{~cm}^{-1}$ (Ander and Messner, 1998).

\section{Tyrosinase assay}

Tyrosinase activity was determined in reaction mixture of $2 \mathrm{ml}$ containing $500 \mu \mathrm{l}$ of $0.01 \%$ catechol in $500 \mu 1$ of $0.1 \mathrm{M}$ phosphate buffer (pH 7.4) and $1 \mathrm{ml}$ of cell free culture at $495 \mathrm{~nm}$ (Zhang and Flurkey, 1997).

\section{Lingnin peroxidase (LiP) assay}

LiP (Lingnin Peroxidase) activity was determined by monitoring the formation of propanaldehyde at $547 \mathrm{~nm}$ in a reaction mixture of $2.5 \mathrm{ml}$ containing $500 \mu \mathrm{l}$ of 100 $\mathrm{mM}$ n-propanol, $500 \mu \mathrm{l}$ of $250 \mathrm{mM}$ tartaric acid, $500 \mu 1$ of $10 \mathrm{mM} \mathrm{H}_{2} \mathrm{O}_{2}$ and $1 \mathrm{ml}$ of cell free culture (Shanmugam et al., 1999) at 547 nm. 


\section{MnP (Manganese Peroxidase) assay}

The reaction mixture contained $500 \mu \mathrm{l}$ of 50 $\mathrm{mM}$ sodium malonate buffer ( $\mathrm{pH} 4.5$ ), $25 \mu \mathrm{l}$ of $20 \mathrm{mM} \mathrm{MnCl} 2$ solution, $415 \mu \mathrm{l}$ of distilled water and $50 \mu \mathrm{pf} \mathrm{MnP}$. The reaction was started by adding $20 \mu \mathrm{l}$ of $10 \mathrm{mM} \mathrm{H}_{2} \mathrm{O}_{2}$. The extinction of the solution was measured photometrically at the wavelength $547 \mathrm{~nm}$ $\left(\varepsilon_{270}=11.59 \mathrm{mmol}^{-1} \mathrm{~cm}^{-1}\right.$ ) (Wariishi et al., 1992).

\section{Azo Reductase Assay}

Assay was carried out in cuvettes with a total volume of $1 \mathrm{ml}$ using colorimeter. The reaction mixture consists of $400 \mu \mathrm{l}$ of potassium phosphate buffer with $200 \mu 1$ of sample and $200 \mu 1$ of reactive dyes $(500 \mathrm{mg} / \mathrm{l})$. The reaction was started by addition of $200 \mu 1$ of NADH $(7 \mathrm{mg} / \mathrm{ml})$ and was monitored photometrically at $547 \mathrm{~nm}$. The linear decrease of absorption was used to calculate the azoreductase activity. One unit of azoreductase can be defined as the amount of enzyme required to decolorize $1 \mu \mathrm{mol}$ of Trypan Blue per minute.

\section{SDS PAGE of Azoreductase}

SDS was excluded from both electrophoresis system and sample buffer. Native gel was cast with $12 \%$ resolving gel and $4 \%$ stacking gel. $0.1 \%$ Carboxy methyl cellulose was added to the resolving gel to facilitate binding of Trypan Blue dye. Crude protein extract was mixed with sample buffer (without SDS and $\beta$-mercaptoethanol) and run on the gel under native conditions. Azoreductase enzyme was located on the gel by activity staining. For this, the gel was washed two to three times in $50 \mathrm{mM}$ phosphate buffer $(\mathrm{pH} 7)$ and stained with $100 \mu \mathrm{M}$ Tryphan Blue. The gel was then transferred to phosphate buffer containing 2 $\mathrm{mM}$ NADH. Appearance of colorless band against blue background (original band) in 15-
20 min indicated the location of active azoreductase enzyme. (Ausubel et al., 1987).

\section{Results and Discussion}

\section{Isolation, Screening and Identification of Bacterial Strains Decolorizing Textile Dyes}

The results shown in Table. 1 revealed that 04 bacterial isolates, designated as HB1 to HB4 were found to be capable of decolorizing Trypan Blue (Fig. 1). Out of 04 isolates, HB3 was found to be the superior strain with the highest decolorization efficiency $(96.60 \%)$. Morphological, cultural and biochemical characteristics of HB3 strains were tabulated in Table.3. On the basis of the above mentioned characteristic features and by the comparison with "Bergey's manual of Determinative Bacteriology", the isolate HB3 was identified as Bacillus sp. Strain HB3 (Table. 2). The extent of dye decolorization of Trypan Blue by the bacterial isolates (HB1 to HB4) is shown in Fig. 2.

\section{Optimization of Dye Decolorizing Ability of HB3 Isolate}

\section{Effect of Incubation Time}

Dye decolorization by Bacillus sp. Strain HB3 was found to be growth dependent, since considerable dye decolorization was noticed in the fermentation broth as soon as the bacterial strains entered the late exponential phase and the activity reached the maximum level in stationary phase after $24 \mathrm{~h}$ of incubation (Fig. $3)$.

\section{Effect of Temperature}

The influence of incubation temperature on the decolorization of Trypan Blue by Bacillus sp. HB3 was studied at temperatures ranging from $25-45{ }^{\circ} \mathrm{C}$. The color removal efficiency of the bacterial isolate (HB3) achieved highest 
levels $(94.02 \%)$ at $35^{\circ} \mathrm{C}$, after $24 \mathrm{~h}$ of incubation. However, incubation at temperatures below $30^{\circ} \mathrm{C}$ and above $40^{\circ} \mathrm{C}$ was found to be down regulating the decolorization percentage of the isolate (Fig. 4).

\section{Effect of pH}

Dye decolorization efficiency of Bacillus sp. HB3 against Trypan Blue was detected over a broad range of $\mathrm{pH}$ (5.0-9.0), with optimum decolorization of $(87.54 \%)$ being exhibited at neutral $\mathrm{pH}$ (7.0). At slightly alkaline $\mathrm{pH}(8.0)$, decolorization efficiency of the isolate was found to be effective (69.54\%) (Fig. 5).

\section{Effect of Dye Concentration}

The results revealed that the decolorization rate of the isolates was optimized in the presence of initial dye concentration of 100 ppm (Fig. 6).

As the dye concentration increased in the culture medium, a gradual and directly proportional decline in color removal was attained.

At high concentration (500 ppm), Trypan Blue greatly suppressed decolorization ability of Bacillus sp. HB3.

Table.1 Bacterial Strains Decolorizing Trypan Blue (HB1- HB4)

\begin{tabular}{|c|c|c|}
\hline S. No & Isolates & \% of Decolorization \\
\hline $\mathbf{1 .}$ & HB1 & $64.66 \%$ \\
\hline $\mathbf{2 .}$ & HB2 & $60.64 \%$ \\
\hline $\mathbf{3 .}$ & HB3 & $\mathbf{9 6 . 6 0 \%}$ \\
\hline $\mathbf{4 .}$ & HB4 & $53.13 \%$ \\
\hline
\end{tabular}

Table.2 Morphological, Cultural and Biochemical Characteristics of HB3 Strain

\begin{tabular}{|c|c|c|}
\hline S. No & Test characteristics & Bacterial Isolate (HB3) \\
\hline I. & Morphological characteristics & \\
\hline 1. & Colony morphology & Smooth, large, translucent. \\
\hline 2. & Cell morphology & Rod shape \\
\hline 3. & Gram reaction & +ve \\
\hline 4. & Motility & $+\mathrm{ve}$ \\
\hline II. & Physiological characteristics & \\
\hline 5. & Growth under aerobic condition & $+\mathrm{ve}$ \\
\hline 6. & Growth under anaerobic condition & $-\mathrm{ve}$ \\
\hline 7. & Growth in Liquid medium & Turbid \\
\hline III. & Biochemical characteristics & \\
\hline 8. & Catalase & +ve \\
\hline 9. & Oxidase & $-\mathrm{ve}$ \\
\hline 10. & IMVIC & $(-+++)$ \\
\hline 11. & Triple Sugar Iron test & $\mathrm{AK} / \mathrm{AK}$, no $\mathrm{H}_{2} \mathrm{~S} \&$ no gas \\
\hline 12. & Urease test & $+\mathrm{ve}$ \\
\hline 13. & Nitrate reduction test & $-\mathrm{ve}$ \\
\hline
\end{tabular}


Fig.1 Trypan Blue before and after decolorization in Nutrient Broth

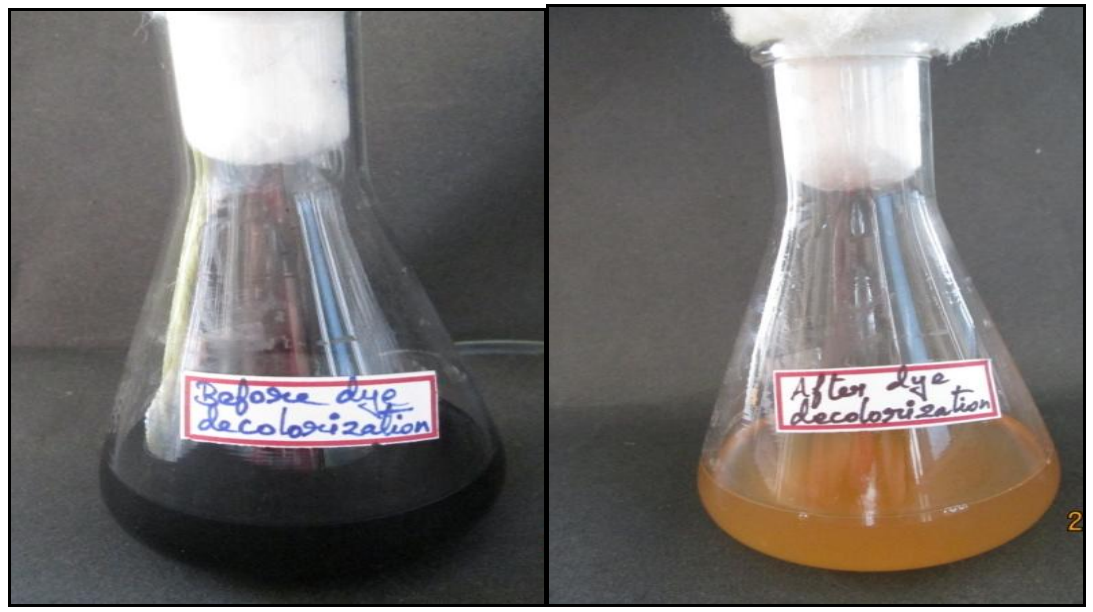

Fig.2 Decolorization Efficiency of Bacterial Isolates towards Trypan Blue

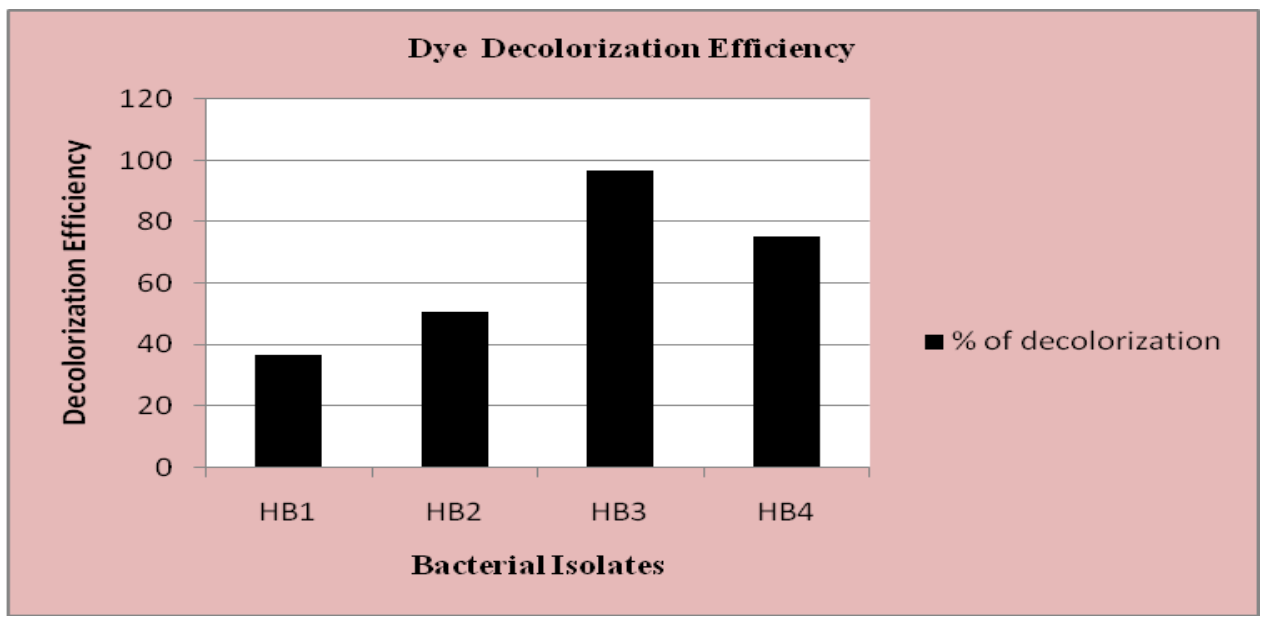

Fig.3 Effect of Incubation Time on Decolorization of Trypan Blue by Bacillus sp. HB3

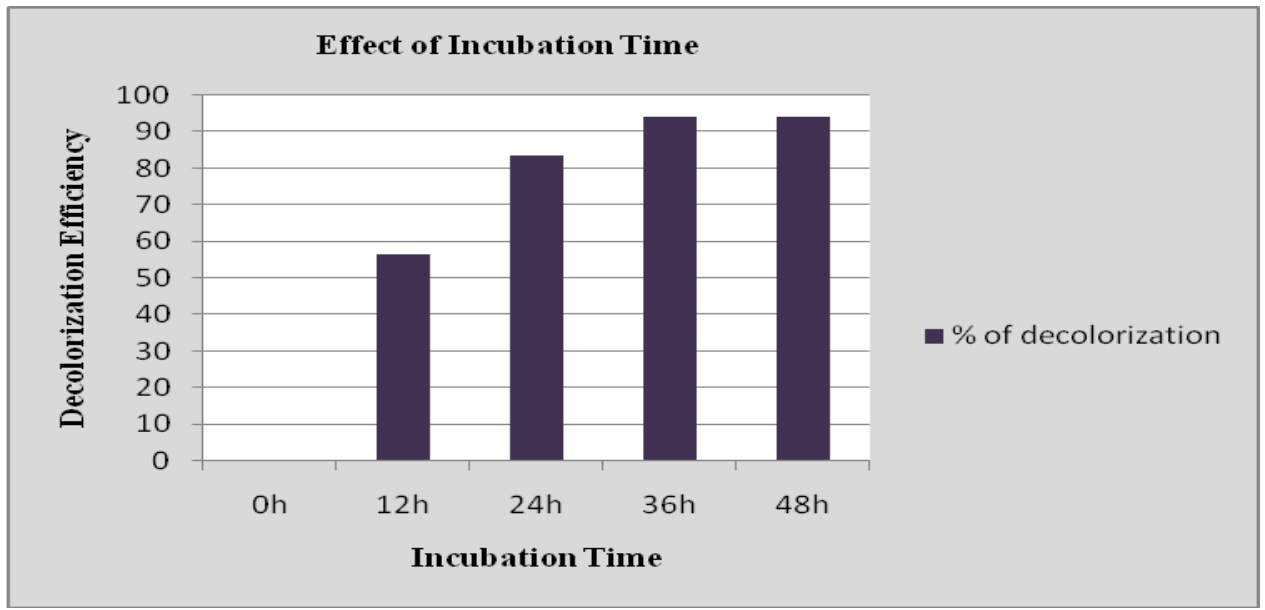


Fig.4 Effect of Temperature on Decolorization of Trypan Blue by Bacillus sp. HB3

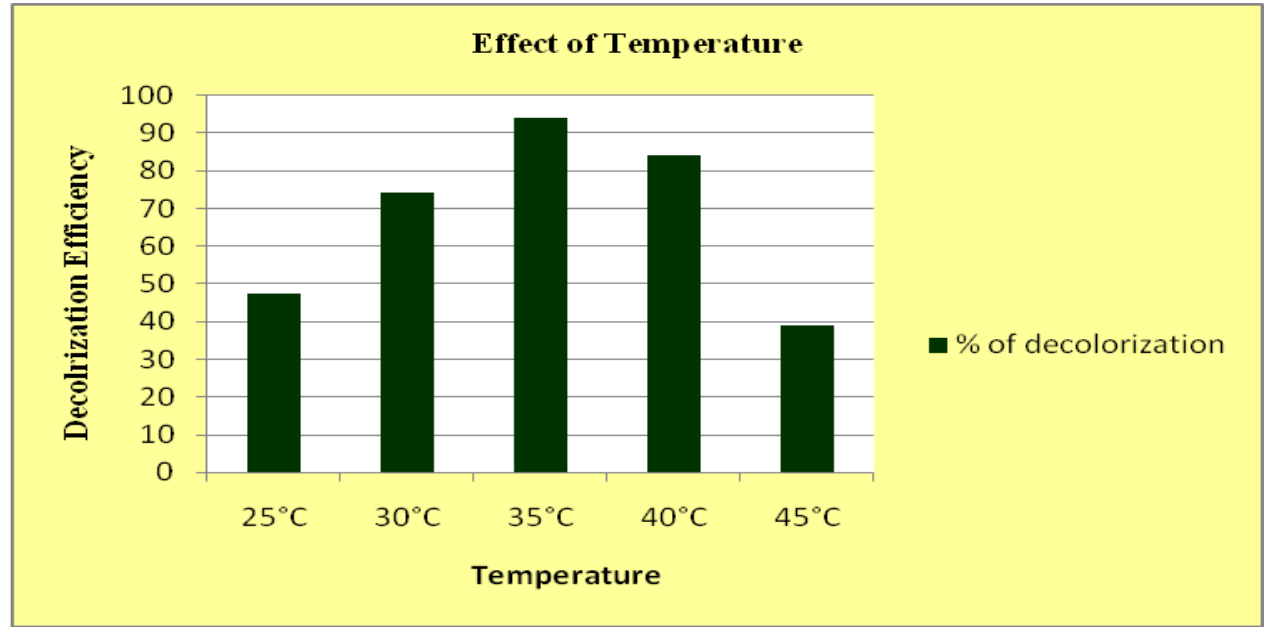

Fig.5 Effect of pH on Decolorization of Trypan Blue by Bacillus sp. HB3

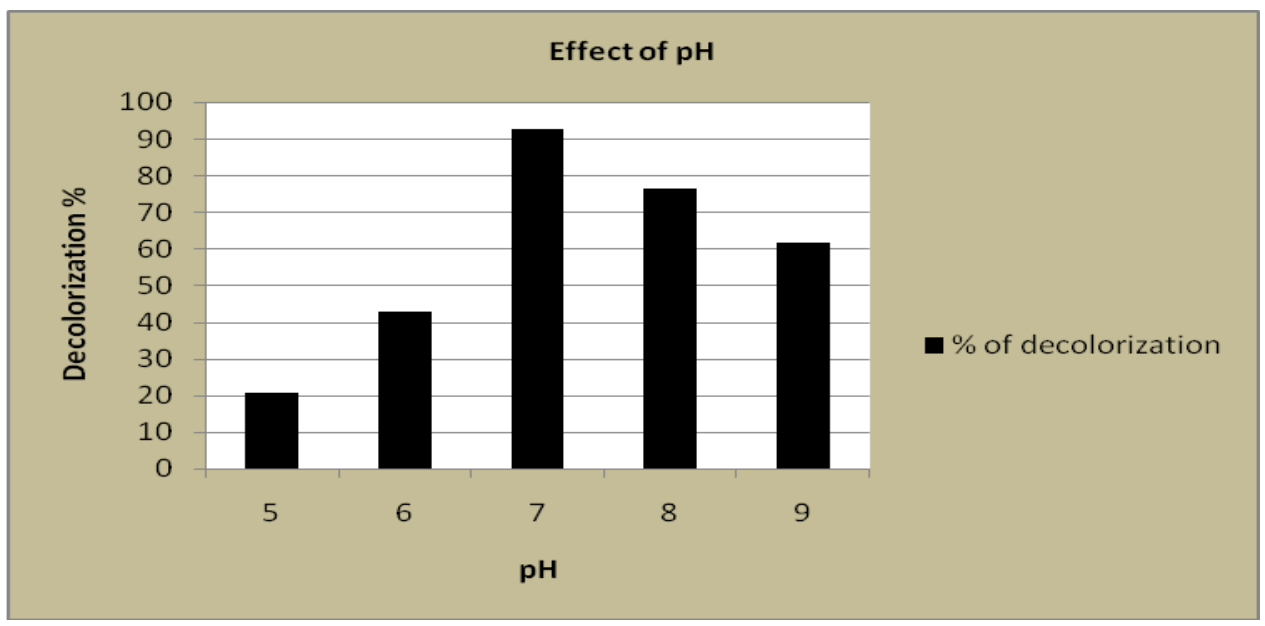

Fig.6 Effect of Dye Concentration on Decolorization of Trypan Blue by Bacillus sp. HB3

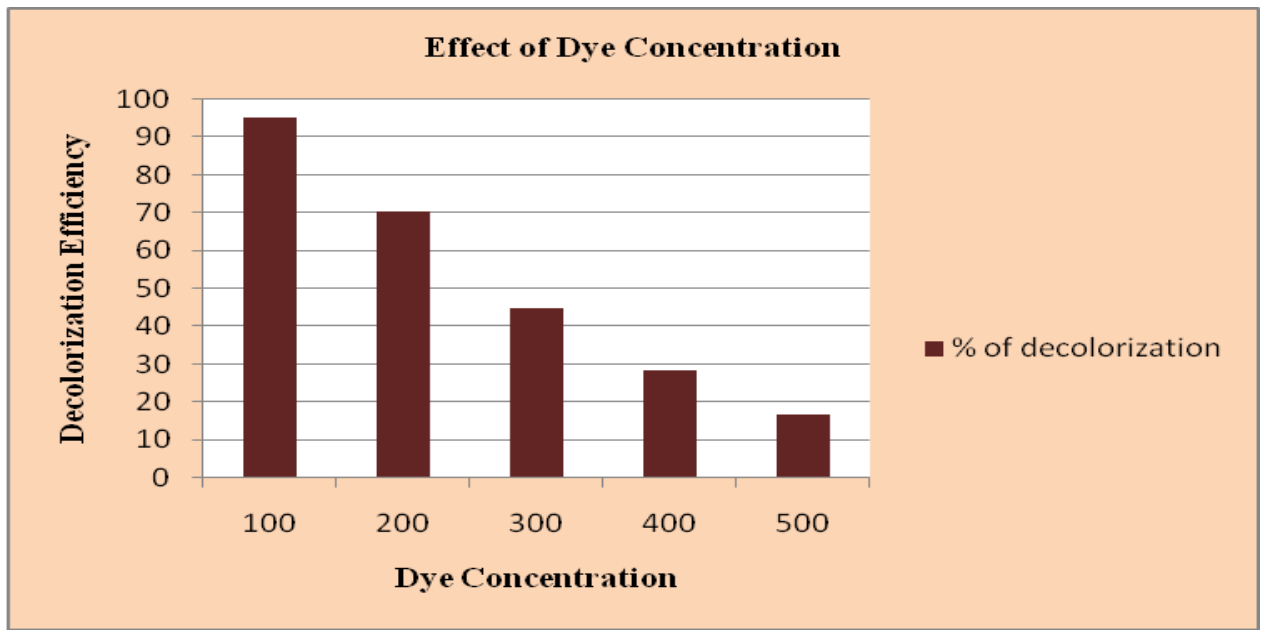


Fig.7 Effect of Carbon Sources on Decolorization of Trypan Blue by Bacillus sp. HB3

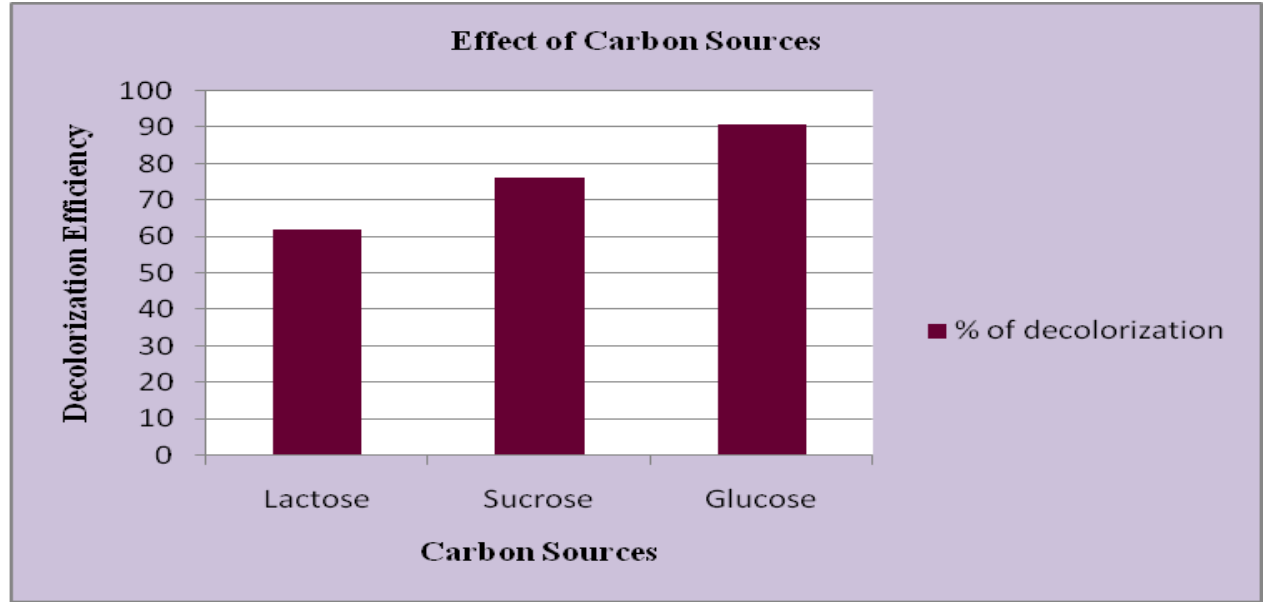

Fig.8 Effect of Nitrogen Sources on Decolorization of Trypan Blue by Bacillus sp. HB3

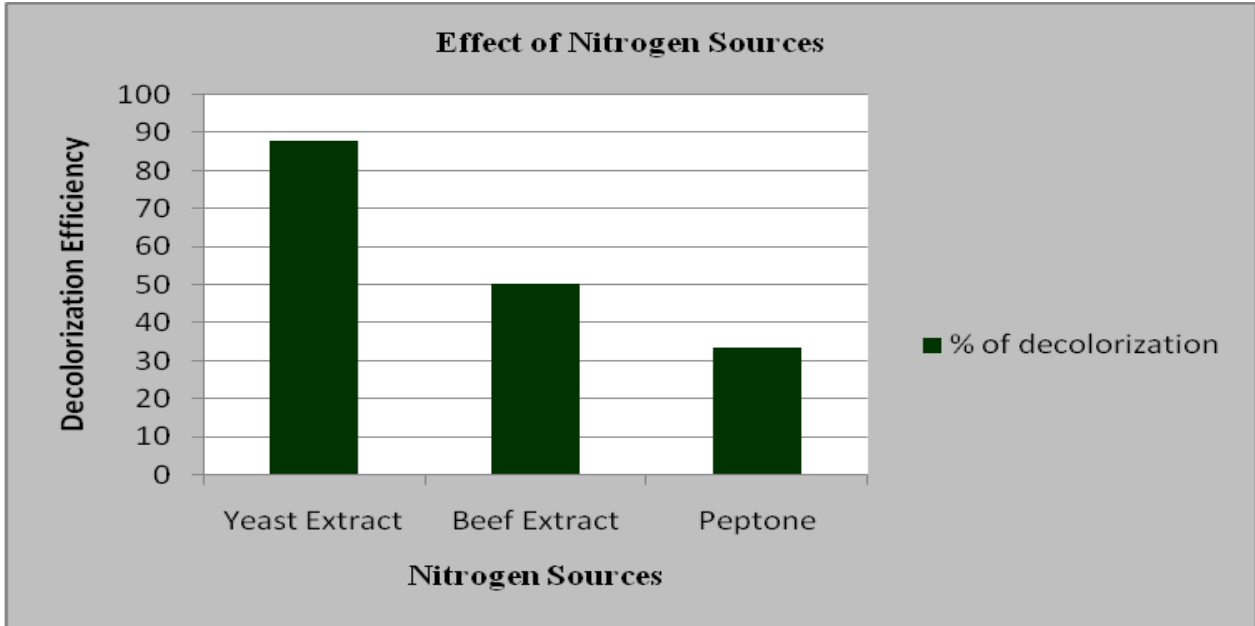

Fig.9 Extracellular Decolorizing Enzyme production by Bacillus sp. HB3

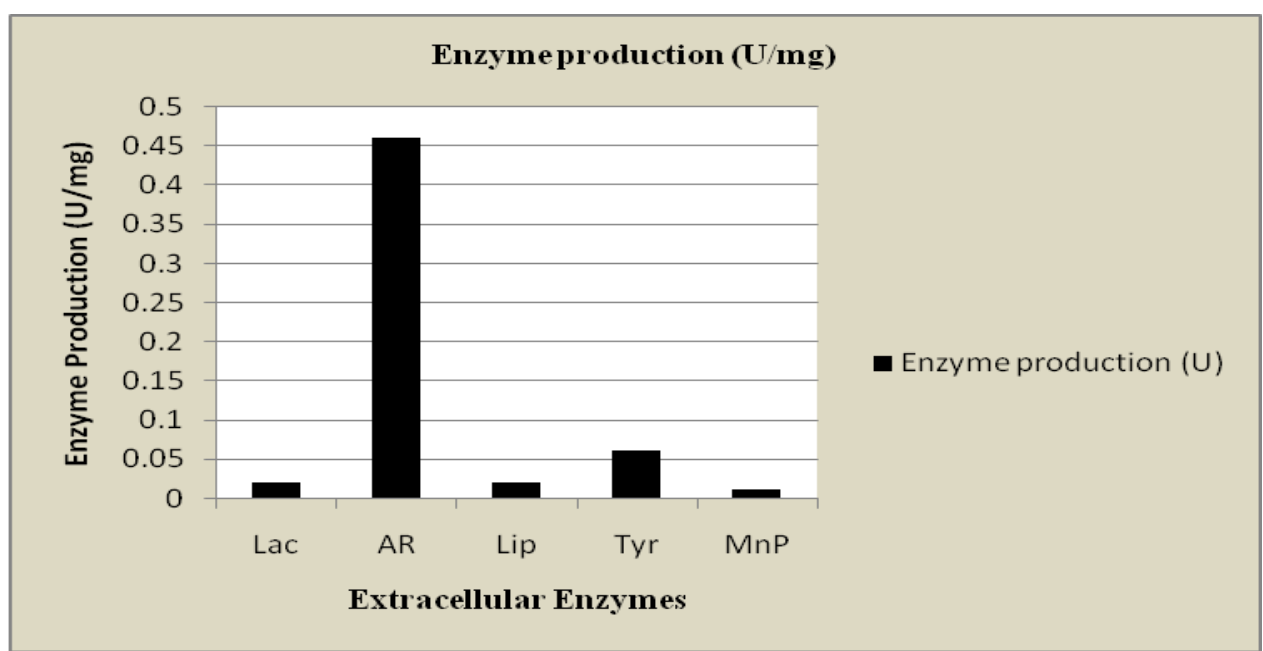


Fig.10 Azo reductase Enzyme Activity of Bacterial Isolate (HB3) on SDS PAGE

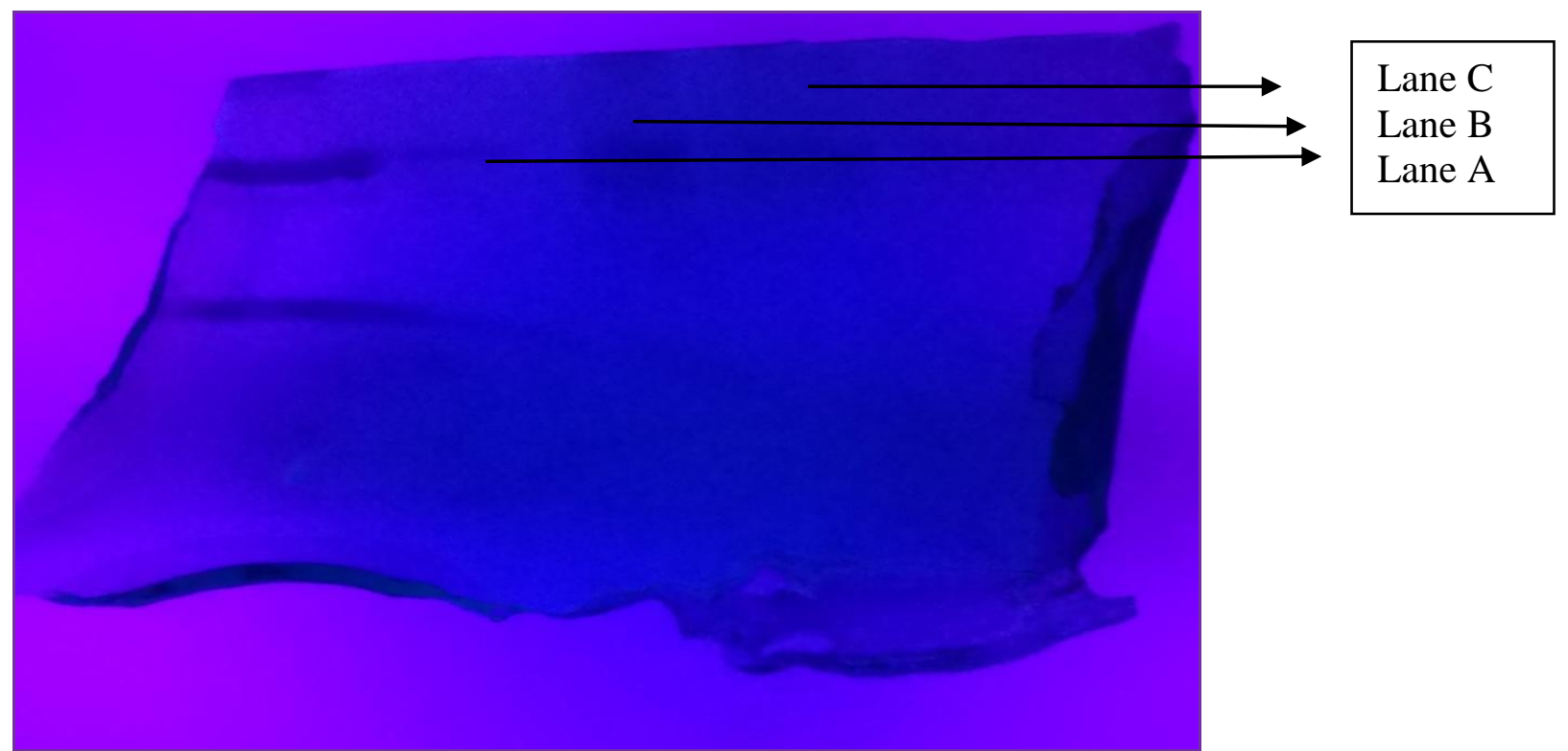

Lane A: SDS-PAGE Molecular Weight Standards

Lane B: Sample

Lane C: Bovine Serum Albumin

\section{Effect of Carbon and Nitrogen Sources}

The bacterial isolate HB3 was able to utilize most of the carbon sources tested, whereas glucose instigated maximum decolorization efficiency $(90.93 \%)$ (Fig. 7).

Among the various nitrogen sources tested, yeast extract was found to be the superior source in maximizing decolorizing ability (87.90\%) (Fig. 8).

Enzymatic assay for decolorization of Trypan Blue

The culture supernatant of HB3 cells that mediated the decolorization of Trypan Blue was screened for the presence of dye decolorizing enzymes such as Azoreductase, Laccase, Tyrosinase, Lignin Peroxidase, MnP (Manganese peroxidase). Azoreductase was found to be the dominant enzyme $(0.46 \mathrm{U} \mathrm{mg}$ -1 protein), whereas Laccase, Tyrosinase, Lignin peroxidase, MnP (Manganese Peroxidase were found to be secreted in very trace amounts $\left(0.02,0.06,0.02,0.01 \mathrm{U} \mathrm{mg}^{-1}\right.$ protein respectively) (Fig. 9).

\section{Azo Reductase Assay and SDS PAGE analysis}

Crude protein extract obtained from Bacillus sp. HB3 cells was found to decolorize Trypan Blue dye using NADH as electron donor. Specific activity of the azoreductase enzyme was found to be $0.46 \mathrm{U} \mathrm{mg}^{-1}$ protein (Fig. 13). The crude protein extract subjected to SDS-PAGE resulted in the formation of a clear band (original band) against blue back ground which indicates the location of active azoreductase enzyme (Fig. 10).

Environmental biotechnology is constantly expanding its efforts in the biological treatment of colored textile effluents, which is an environmental friendly and low-cost alternative to physico-chemical decomposition processes. The textile industries are multi-chemical utilizing concerns, of which various dyes are of 
importance. During the dyeing process substantial amount of dyes and other chemicals are lost in the wastewater (Vaidya and Datye, 1982). An important element in guiding the direction and development of decolorization technology should logically depend upon a sound scientific knowledge, which undoubtedly warrants for further research. In view of the need for a technically and economically satisfying treatment technology, a flurry of emerging technologies are being proposed and tested at different stages of commercialization. Broader validation of these new technologies and integration of different methods in the current treatment schemes will most likely in the near future, render these both efficient and economically viable. The presence of dyes imparts an intense color to effluents, which leads to environmental as well as aesthetic problems (Singh and Singh, 2006).

Temperature variation had a significant effect on the decolorization of Trypan Blue by Bacillus sp. strain HB3. The rate of decolorization was found to be optimized at $35^{\circ} \mathrm{C}$ after $24 \mathrm{~h}$ of incubation.

The rate of decolorization decreased with the decrease in temperature. This fact implies that the local temperature in the microenvironment of the effluent samples has a very significant effect on the decolorization activity (Moosvi et al., 2005). Decolorization activity of Bacillus sp. strain HB3 was significantly suppressed at temperatures more than $40^{\circ} \mathrm{C}$, which might be due to the loss of cell viability or denaturation of the enzymes responsible for the decolorization at elevated temperatures. The most biologically feasible $\mathrm{pH}$ for the decolorization of Trypan Blue by Bacillus sp. strain HB3 was found to be 7.0. In contrast, optimal $\mathrm{pH}$ values for the decolorization of Reactive Red RB by a microbial consortium was found to be 8.0 (Cetin and Donmez, 2006). The foregoing results suggest the potential of utilizing Bacillus sp. strain HB3 to degrade textile effluent containing synthetic textile dyes via; appropriate bioreactor operation.

\section{References}

Aksu, Z., Kilic, N., Ertugrul, V. and Donmez, G. 2007. Inhibitory effects of chromium (VI) and Remazol black on chromium (VI) and dyestuff removals by Trametes versicolor. Enz. Microbial Technol., 40: 1167-1174.

Ander, P. and Messner, K. 1998. Oxidation of 1 - hydroxybenzotriazole by by laccase and lignin peroxidase. Biotechnolo. Tech., 191- 5.

Asad, S., Amoozegar, M.A., Pourbabaee, A.A., Sarbolouki, M.N. and Dastgheib, S.M. 2007. Decolorization of textile azo dyes by newly isolated halophilic and halotolerant bacteria. Bioresources Technology, 98: 2082-2088.

Ausubel, F.M., Brent, R., Kingston, R.E., Moore, D.D., Seidman, J.G., Smith, J.A. and Struhl, K. 1987. Current protocols in molecular biology. New York, Wiley.

Cetin, D. and Denmez, G. 2006. Decolorization of reactive dyes by mixed cultures isolated from textile effluent under anaerobic conditions. Enz. Microb. Technol., 38: 926 - 930.

Chang, J.S., Chou, C. and Chen, S.Y. 2001. Decolorization of azo dyes with immobilized Pseudomonas luteola, Water Sci. Technol., 43: 261-269.

Hemapriya, J., Rajesh Kannan and Vijayanand, S. 2010. Bacterial decolorization of textile azo dye Direct Red - 28 under aerobic conditions. J. Pure Appl. Microbiol., 4(1): 309 - 314.

Moosvi, S., Kehaira, H. and Madamwar, D. 2005. Decolorization of textile dye Reactive Violet 5 by a newly isolated bacterial consortium RVM 11. World J Microbiol Biotechnol., 21: 667 - 672. 
Novotny, C., Rawal, B., Bhatt, M., Patel, M., Aek, V. and Molitoris, H.P. 2001. Capacity of Irpex lacteus and Pleurotus ostreatus for decolorization of chemically different dyes, J. Biotechnol., 89: 113-122.

O'Mahony, T., Guibal, E. and Tobin, J.M., 2002. Reactive dye biosorption by Rhizopus arrhizus biomass. Enzyme Microb. Technol., 31: 456-463.

Ozturk, A. and Abdullah, M. 2006. Toxicological effect of indole and its azo dye derivatives on some microorganisms under aerobic conditions. Science of the Total Environment, 358: 137-142.

Pagga, U. and Brown, D. 1986. The degradation of dyestuffs. Part II. Behaviour of dyestuffs in aerobic biodegradation tests, Chemosphere, 15: 479-491.

Pandey, A. Singh, P. and Lyengar, L. 2007. Bacterial decolorization and degradation of azo dyes. Int Biodeterior Biodegrad, 59: 73 - 84 .

Rajaguru, P., Kalaiselvi, K., Palanivel, M. and Subburam V. 2000. Biodegradation of azo dyes in a sequential anaerobicaerobic system, Appl. Microbiol. Biotechnol., 54: 268-273.

Rieger, P.G., Meier, H.M., Gerle, M., Vogt, U., Groth, T. and Knackmuss, H.J., 2002. Xenobiotics in the environment: present and future strategies to obviate the problem of biological persistence. J. Biotechnol., 94: 101-123.
Shanmugam, V., Kumari, M. and Yadav, K.D. 1999. n-proponol as substrate for assaying the lignin peroxidase activity of Phanerochaete chrysoporium. Indian Journal of Biochemistry and Biophyscis, 36: $39-43$.

Singh, V.K. and Singh, J. 2006. Toxicity of industrial wastewater to the aquatic plant Lemna minor L. J. Environ Biol, 27: $385-390$.

Stolz, A. 2001. Basic and applied aspects in the microbial degradation of azo dyes, Appl. Microbiol. Biotechnol., 56: 6980.

Vaidya, A.A. and Datye, K. V. 1982. Environmental pollution during chemical processing of synthetic fibres. Colourage, 14: 3 - 10 .

Vijaykumar, M.H., Vaishampayan, P.A., Shouche, Y.S. and Karegoudar, T.B. 2007. Decolourization of naphthalene containing sulfonated azo dyes by Kerstersia sp strain VKY1. Enzyme Microbial Technology, 40: 204-211.

Wariishi, H., Valli, K. and Gold, M.H. 1992. Manganese (II) oxidation by manganese peroxidase from the basidiomycete Phanerochaete. Kinetic mechanism and role of chelators, chrysoporium. J.Biol Chem. 23: $688-95$.

Zhang, X. and Flurkey, W.H. 1997. Phenoloxidases in portabella mushrooms. Journal of Food Science, 62: $97-100$.

\section{How to cite this article:}

Jeevitha P., D. Manjula, I. Ramya and Hemapriya J. 2018. Bioremediation and Detoxification of Trypan Blue by Bacillus sp. Isolated from Textile Effluents. Int.J.Curr.Microbiol.App.Sci. 7(07): 4381-4391. doi: https://doi.org/10.20546/ijcmas.2018.707.511 